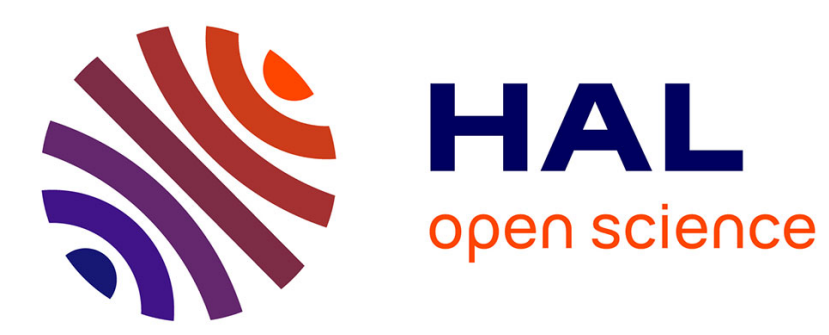

\title{
Electrochemical Insertion of CO2 into Silver in a Large Extent
}

\author{
Jacques Simonet
}

\section{To cite this version:}

Jacques Simonet. Electrochemical Insertion of CO2 into Silver in a Large Extent. Electrochemistry Communications, 2015, 58, pp.11-14. 10.1016/j.elecom.2015.05.011 . hal-01158457

\section{HAL Id: hal-01158457 https://hal-univ-rennes1.archives-ouvertes.fr/hal-01158457}

Submitted on 12 Nov 2015

HAL is a multi-disciplinary open access archive for the deposit and dissemination of scientific research documents, whether they are published or not. The documents may come from teaching and research institutions in France or abroad, or from public or private research centers.
L'archive ouverte pluridisciplinaire HAL, est destinée au dépôt et à la diffusion de documents scientifiques de niveau recherche, publiés ou non, émanant des établissements d'enseignement et de recherche français ou étrangers, des laboratoires publics ou privés. 


\title{
Electrochemical Insertion of $\mathrm{CO}_{2}$ into Silver in a Large Extent
}

\author{
Jacques Simonet ${ }^{*}$ \\ Laboratoire MaSCE, UMR 6226, Université de Rennes 1, Campus de Beaulieu, 35042 Rennes \\ Cedex, France.
}

\begin{abstract}
The reduction of solutions of carbon dioxide (saturated at the room temperature in organic polar solvents such as acetonitrile, AN, or N,N-dimethylfomamide, DMF, containing tetraalkylammonium salts TAAX) was achieved at smooth silver electrodes. Under these conditions, reduction steps were obtained beyond $-1.7 \mathrm{~V}$ vs $\mathrm{Ag} / \mathrm{AgCl}$ with exact potentials depending on the size of $\mathrm{TAA}^{+}$cations. An unexpected behaviour is noticeable with tetramethylammonium salts $\left(\mathrm{TMA}^{+} \mathrm{X}^{-}\right)$leading to a progressive electrode inhibition upon scans or fixed potential electrolysis at $\mathrm{E}<-2 \mathrm{~V}$. These results are in agreement with the formation of a thick layer of the form $\left\{\mathrm{Ag}-\mathrm{CO}_{2}{ }^{-}, \mathrm{TMA}^{+}\right\}$strongly sensitive to di-oxygen, water, organic $\pi$-acceptors; this layer is considered as a reducing reagent of low chemical stability and can be oxidized before silver. Placed under pure argon atmosphere, the layer decomposes - presumably by instability of $\mathrm{TMA}^{+}$in reducing media that permits trapping of large superficial amounts of $\mathrm{CO}_{2}$ in the material supposing the formation of multi-layers of $\mathrm{CO}_{2}$ (up to $5 \times 10^{-6} \mathrm{~mol} \mathrm{~cm} \mathrm{~cm}^{-2}$ ). These novel $\left\{\right.$ silver- $\left.\mathrm{CO}_{2}\right\}$ materials could be seen as dual catalytic-electrophilic electrodes.
\end{abstract}

Key-words: Silver electrodes; modified electrodes; cathodic carboxylation; $\mathrm{Ag}-\mathrm{CO}_{2}$ dual materials.

\section{Corresponding author:}

Jacques Simonet,

Tel: +33 (0) 2232362 92, jacques.simonet@univ-rennes1.fr

\section{Introduction}

Undoubtedly, electrochemistry is a very valuable method for insertion of free radicals and ions inside carbon and metallic matrixes. This is an interesting way for creating new interfaces, permitting creation of new catalytic electrodes both within the anodic and cathodic ranges. Among wide possibilities of transforming materials (especially carbons and graphites), one may find in a recent literature works that quoted reactivity of gold [1] and 
mercury via tetraalkylammonium $\left(\mathrm{TAA}^{+}\right)$amalgams [2], of platinum and palladium by insertion of salts or/cations within the cathodic range [3]. Still in the field of the insertion of $\mathrm{TAA}^{+}$cations, their cathodic reactivity with post-transition metals (antimony, tin, lead) deserves being quoted [4]. In most of cases, such reaction can be considered as the formation of new reducing reagents [5] and should be carried out in an inert atmosphere.

Silver is presently considered as a fascinating metal for its catalytic properties especially in the domain of the scission of carbon-halogen bonds [6,7], and despite its perspective capacities to act as a reducing entity, attempts to modify surfaces or to insert ions into Ag matrixes do not presently appear to have been achieved.

The present contribution concerns small electroactive molecules that can act as vectors to diffuse into metals under their reduced or oxidized form(s) and then inducing the paired insertion of the counter-ion of supporting electrolyte. The case of carbon dioxide is questionable because its reduction potential appears very depending on the electrode material and the electrolyte: obviously, it possesses a strong capability to provoke catalyses and react with cathode materials; glassy carbon [8], graphite [9], or showing specific capacities for catalyzing couplings (e.g. formation of oxalate on lead [10]).

For the first time, the reduction of $\mathrm{CO}_{2}$ was performed at smooth silver in the presence of TAAX salts in polar aprotic solvents. The great novelty of this approach is that it allowed to disclose that a reduced form of $\mathrm{CO}_{2}$ (presumably, the anion radical), exclusively when combined with $\mathrm{TMA}^{+}$, may react with silver leading to a large insertion into the electrode matrix until a total surface inhibition, which is manifested by the drop of conduction in the modified metal interface. The insertion product is considered as a reducing reagent. Moreover, a specific oxidation step (that removes the inhibition) was detected, and the reactivity of silver towards carbon dioxide insertion could be proved by change of its pristine structure. Hereafter, is described a first approach concerning $\mathrm{CO}_{2}$ that quite certainly deserves further extended refinements and can certainly be applied (after exploratory works guided by the present study) to the unexpected carboxylation of a large series of solid materials currently used in electrochemistry.

\section{Experimental section}

\subsection{Salts and solvents}

In the present work, $0.1 \mathrm{M}$ solutions of tetramethylammonium, tetraethylammonium, tetra- $n$-butylammonium tetrafluoroborates $\left(\mathrm{TMABF}_{4}, \mathrm{TEABF} 4\right.$, and TBABF $)$ and tetra- $n$ hexyliodide (THAI) in dimethylformamide (DMF) and acetonitrile (AN) were used. Salts and solvents were purchased from Aldrich (quality for syntheses). It is worth mentioning that the procedures given hereafter do not require extremely dry solutions so the solvents were used as 
received (water content $>800 \mathrm{ppm}$ ). For excluding oxygen, all electrochemical experiments were performed under inert atmosphere bubbling argon through the solution. Alternatively, corresponding to the aim of the study, liquid electrolytes were saturated with $\mathrm{CO}_{2}$ (bubbling for $5 \mathrm{~min}$ at room temperature) purchased at Air Liquide.

The reported potentials are all referred to aqueous $\mathrm{Ag} / \mathrm{AgCl} / \mathrm{KCl}_{\text {sat }}$ electrode. The electrochemical instrumentation has been previously described $[4,5]$.

\subsection{Working electrodes}

All silver and glassy carbon (GC) electrodes used in voltammetry had an apparent surface area of $0.8 \mathrm{~mm}^{2}$. Before using silver and glassy carbon electrode, their surfaces were carefully polished with silicon carbide paper (Struers 500 and 1200) or with Norton polishing paper (type 02 and 03) and rinsed with water, then alcohol and at last with acetone. After recurrent scans or fixed potential electrolyses, silver electrodes were eventually sonicated for two minutes. Finally, before analysis, the electrodes were dried with a hot air flow during about 30 s. Coulometry measurements and electrolyses reported in this work were carried out using three-electrode cells with a total catholyte volume of about $5 \mathrm{~mL}$.

\subsection{Organic materials}

All organic compounds used for testing silver materials modified by insertion of $\mathrm{CO}_{2}$ were purchased from Merk and Aldrich.

\section{Experimental results}

\subsection{Experimental evidence of a large carbon dioxide insertion in silver bulk}

At first sight, the procedure described in this contribution may appear to the reader totally unexpected. The simultaneous blend of silver metal on the one hand, and a moderate pressure of $\mathrm{CO}_{2}$ when using an $\mathrm{M}^{+} \mathrm{X}^{-}$(not too bulky $\mathrm{M}^{+}$and anodically stable $\mathrm{X}^{-}$) electrolyte on the other hand, meeting in a confined reducing space at $\mathrm{E}<-1.8 \mathrm{~V}$ may produce a strongly inhibiting organometallic species under specific conditions. More specifically, as featured in Scheme 1, the electrochemical technique may provide a very easy way to form an organometallic entity (proposed to be written as $\left\{\mathrm{Ag}-\mathrm{CO}_{2}-\mathrm{M}\right\}$ ). The experiments described hereafter used essentially solutions of tetramethylammonium tetrafluoroborate $\left(\mathrm{TMA}^{+} \mathrm{BF}_{4}{ }^{-}\right)$ in DMF saturated in $\mathrm{CO}_{2}$ (room temperature), considered as a catholyte in which a smooth $\mathrm{Ag}$ electrode was plunged. Fixed potential electrolyses at $\leq 1.8 \mathrm{~V}$ led to a quite fast inhibition of the electrode surface until very small current densities are obtained. Voltammetry (Figure 1, 
curves A) permits to disclose the progressive decay of the electron exchange that suggests the formation of a thick layer of $\left\{\mathrm{Ag}-\mathrm{CO}_{2}-\mathrm{M}\right\}$ of weak conductivity. Resting the covered electrode at $0 \mathrm{~V}$ under the flow of argon permits to replace $\mathrm{CO}_{2}$ atmosphere inside the cell, however silver electrode still reacts with $\mathrm{CO}_{2}$ (Figure 1, B), suggesting the Ag matrix still contains quite large amounts of carbon dioxide really inserted into the metal.

Figure 1 (curves C) illustrates the peculiar action of $\mathrm{TMA}^{+}$in the insertion process. Bulkier $\mathrm{TAA}^{+}$do not favour the $\mathrm{CO}_{2}$ electro-activity, neither its insertion into silver. $\mathrm{Na}^{+}$ (associated to $\mathrm{BF}_{4}^{-}$) may be used as well for insertion and supports the importance of the insertion rate in this reaction. A similar process can be achieved in ACN.

MEB analyses do confirm the presence of amorphous or crystalline deposits on the Ag surface (Figure 1, slides D).

\subsection{Evaluation of thickness of the inhibiting $\mathrm{Ag}_{-} \mathrm{CO}_{2}$ layer}

Assuming the inhibitor coverage process to obey a one-electron reaction (1), as proposed in Scheme 1, the main and sharp peak (I) (curve A in Figure 1) may account for the progressive formation of an organometallic species propagating from the surface to the bulk. It is obviously quite thick already at the first scan: $\Gamma_{1}=2.4 \times 10^{-6} \mathrm{~mol} \mathrm{~cm}^{-2}$. Further recurrent scans provoke a regular decay of the peak current until a quasi absence of response between $-1.5 \mathrm{~V}$ and $-2.0 \mathrm{~V}$ after 10 to 12 scans that supposes a progressive filling of the metal. Under the conditions of Figure 1 (scan rate: $50 \mathrm{mV} \mathrm{s}^{-1}$ ), a quasi total inhibition -depending of the scan rate- is observed for $10^{-5} \mathrm{~mol} \mathrm{~cm}^{-2}$. Alternatively, fixed potential electrolyses achieved at $-2.2 \mathrm{~V}$ until a final current density of $5 \mu \mathrm{A} \mathrm{mm} \mathrm{m}^{-2}$ permitted obtaining the reductions implying $>10^{-6} \mathrm{~mol} \mathrm{~cm}^{-2}$. Therefore, this method would enable formation of a large multilayer system (roughly more than $10^{4}$ layers) and one might then admit that organometallic diffusion inside the silver bulk occurs upon short reaction times $(<3 \mathrm{~min})$.

\subsection{Voltammetric analysis of the $\left\{\mathrm{Ag}-\mathrm{CO}_{2}-\mathrm{TMA}\right\}$ multi-layer}

Once the organo-silver layer is formed (3 successive steps (I), total charge: $3.1 \times 10^{-7} \mathrm{~mol}$ $\mathrm{cm}^{-2}$ ) as discussed in $\S 3.1$, its anodic oxidation was achieved as pictured in Figure 2, curves A. Thus, after the insertion of $\mathrm{CO}_{2}$ in the course of the forward scan, a reverse scan up to $+0.7 \mathrm{~V}$ permits to observe an anodic step (II) $\left(\mathrm{E}_{\mathrm{pII}}=0.36 \mathrm{~V}\right.$, charge: $\left.2.9 \times 10^{-7} \mathrm{~mol} \mathrm{~cm}^{-2}\right)$ well different of that of Ag metal. Within this potential interval, the anodic oxidation of $\mathrm{Ag}$ does not appear consecutively to the inhibiting deposit. It is expected that step (II) would correspond to the anodic oxidation of $\left\{\mathrm{Ag}-\mathrm{CO}_{2}-\mathrm{TMA}\right\}$ (reaction (2)) followed by the decomposition according to reaction (3), presumably liberating $\mathrm{CO}_{2}$ and $\mathrm{Ag}^{+}$particles still 
dissociated from the silver mass. In the course of second cathodic scan, one observes another bell-shaped reduction step (III) $\left(\mathrm{E}_{\mathrm{pIII}}=-0.38 \mathrm{~V}\right.$, charge: $\left.3.0 \times 10^{-7} \mathrm{~mol} \mathrm{~cm}{ }^{-2}\right)$ assigned to the reduction of the organo-metallic layer cation or that of $\mathrm{Ag}^{+}$that was shown to be coupled to step II. One may notice that charge values relative to steps I, II, and III are particularly coherent. Also, the experiments achieved in comparable conditions with $\mathrm{Pt}, \mathrm{Pd}$, and $\mathrm{Au}$ exhibit only two steps I and II (no corrosion of the host metal). In all cases, surface analyses of metals after carboxylation processes exhibit attachment of carboxylic groups. There are also some evidences that carbon dioxide partly remains in silver after oxidation (reaction 3) and a total regeneration of the gold electrode for further voltammetric analyses require a stay in oven $\left(60^{\circ} \mathrm{C}\right)$ for a few minutes.

\subsection{About chemistry of $\left\{\mathrm{Ag}-\mathrm{CO}_{2}-\mathrm{TMA}\right\}$}

This complex does not appear to be particularly stable. It is sensitive to air (dioxygen), moisture, and the presence of organic acceptors. For example, as depicted in Figure 2 B, the addition of a primary alkyl iodide RI, to the cell with the charged carboxylated silver electrode (voltammetric response in black) led to a sudden decay in $\mathrm{CO}_{2}$ concentration at the interface (perceived at a maximum of current in red) identical to the first scan during the charge. At the same time, the reduction current corresponding to the catalytic cleavage of RI $\left(\mathrm{E}_{\mathrm{p}} \approx-0.9 \mathrm{~V}\right)$ is small. For comparison, a smooth silver electrode (Figure $2 \mathrm{~B}$ ) led to a much larger reduction step of RI (V). Also, the use of "catalytic-carboxylating" electrodes that combine catalysis by $\mathrm{Ag}$ and the electrophilic properties of inserted $\mathrm{CO}_{2}$ permitted to realise carboxylation of unsaturated hydrocarbons. Finally, peared carboxylation reactions using Ag transients in very thin deposits were successfully accomplished onto graphites and graphenes.

\section{Conclusion}

Here considered as a small-size electroactive molecule, $\mathrm{CO}_{2}$ (gas) may be successfully inserted into silver under specific conditions principally related to the nature of polar organic solvent and the size of the electrolyte cation. The metal is not only carboxylated in surface (small electricity amounts), but also -and considerably- in the Ag bulk. These preliminary results suggest that the insertion is reversible and may be easily anodically $(\mathrm{E}<1.0 \mathrm{~V})$ released; such $\mathrm{CO}_{2}$-charged electrodes can then be considered as a convenient source of $\mathrm{CO}_{2}$ for carboxylation reactions with adapted probes (field of micro-electrochemistry). It is interesting to notice that the cleavage of the silver- $\mathrm{CO}_{2}$ bond reported in this preliminary work is in a certain manner quite similar to the non-Kolbe reaction at carbons [9]. Finally, this reaction could be successfully extended to a large series of metals, in particular Au and Pt. 
Acknowledgements: Professor V. Jouikov (Université de Rennes) is warmly thanked for his fruitful comments on the manuscript.

\section{References}

[1] V. Jouikov, J. Simonet, Electrochem. Commun., 56 (2015) 20.

[2] L. Horner, H. Neumann, Chem. Ber. 98 (1965) 1715.

[3] P. Hapiot, J. Simonet, Electroanal. Chem. 23 (2010) 105.

[4] E. Kariv-Miller, P.B. Lawin, J. Electroanal. Chem. 247 (1988) 345.

[5] E. Kariv-Miller, P. D. Christian, V. Svetlicic, Langmuir, 11 (1995) 1817.

[6] A.A. Isse, B. Giacomo, L. Falciola, M. Rossi, P.R. Mussini, A. Gennaro, J. Appl. Electrochem. 39 (2009) 2217.

[7] A. A. Isse, A. De Giusti, A. Gennaro, L. Falciola, P. R. Mussini, Electrochim. Acta, 51 (2006) 4956.

[8] J. Simonet, Electrochem. Commun., 21 (2012) 22.

[9] V. Jouikov, J. Simonet, Electrochem. Commun., 45 (2014) 32.

[10] V. Jouikov, J. Simonet, Electrochem. Commun., 43 (2014) 67.

[11] C. Amatore, J.-M. Savéant, J. Am. Chem. Soc.103 (1981) 5021.

[12] B.R. Eggins, C. Ennis, R. McConnell, M. Spence, J. Appl. Electrochem., 27 (1997) 706.

[13] M. Jitaru, J. Univ. Chem. Technol. Metallurgy 42 (2007) 333

\section{Figure captions}

\section{Figure 1}

Insertion of $\mathrm{CO}_{2}$ into silver. 
A) Voltammetry of saturated solution of $\mathrm{CO}_{2}$ in $\mathrm{DMF}$ at a stationary silver electrode (area: $0.8 \mathrm{~mm}^{2}$ ). Electrolyte $\mathrm{TMABF}_{4}$. Scan rate: $100 \mathrm{mV} \mathrm{s}^{-1}$. Decay of the peak current after 9 scans. For comparison: B) voltammetry of the same electrode (without contact with air) after an in situ replacement of $\mathrm{CO}_{2}$ by argon.

C) Voltammetry of $\mathrm{CO}_{2}$ at silver electrode in DMF in the presence of different electrolytes. Scan rates: $50 \mathrm{mV} \mathrm{s}^{-1}$. $\mathrm{TMA}^{+}$(black), $\mathrm{THA}^{+}$(green), and $\mathrm{TBA}^{+}$(red).

D) MEB analysis of an Ag pristine surface after electrolysis at $-2.2 \mathrm{~V}$ in the presence of $\mathrm{CO}_{2}$. Amount of electricity: $1.5 \mathrm{C} \mathrm{cm}^{-2}$.

\section{Figure 2}

Voltammetry of the cathodic deposit obtained at $\mathrm{Ag}$ in the presence of $\mathrm{CO}_{2}$ and $\mathrm{TMA}^{+}$.

A) After formation of the deposit (according to (I)), the oxidation of the silver complex (II), scan inversion from $+0.7 \mathrm{~V}$. The cathodic step (III), assigned to the reduction of $\mathrm{Ag}^{+}$arising from the anodic degradation of $\left\{\mathrm{Ag}-\mathrm{CO}_{2}-\mathrm{TMA}\right\}$. For comparison, the electrochemical response of the bare silver surface is shown in red. Scan rate: $50 \mathrm{mV} \mathrm{s}^{-1}$.

B) Deposit of the silver complex (black) prior to adding 1-iodohexane $\left(7 \mathrm{mmol} \mathrm{L}^{-1}\right)$. The C-I cleavage step (V) is very small presumably because the $\mathrm{Ag}-\mathrm{CO}_{2}$ complex reduces the RI compound (red) while a few scans entirely restore the coverage. For comparison, the reduction of the RI at smooth $\mathrm{Ag}$ (blue) is given. 

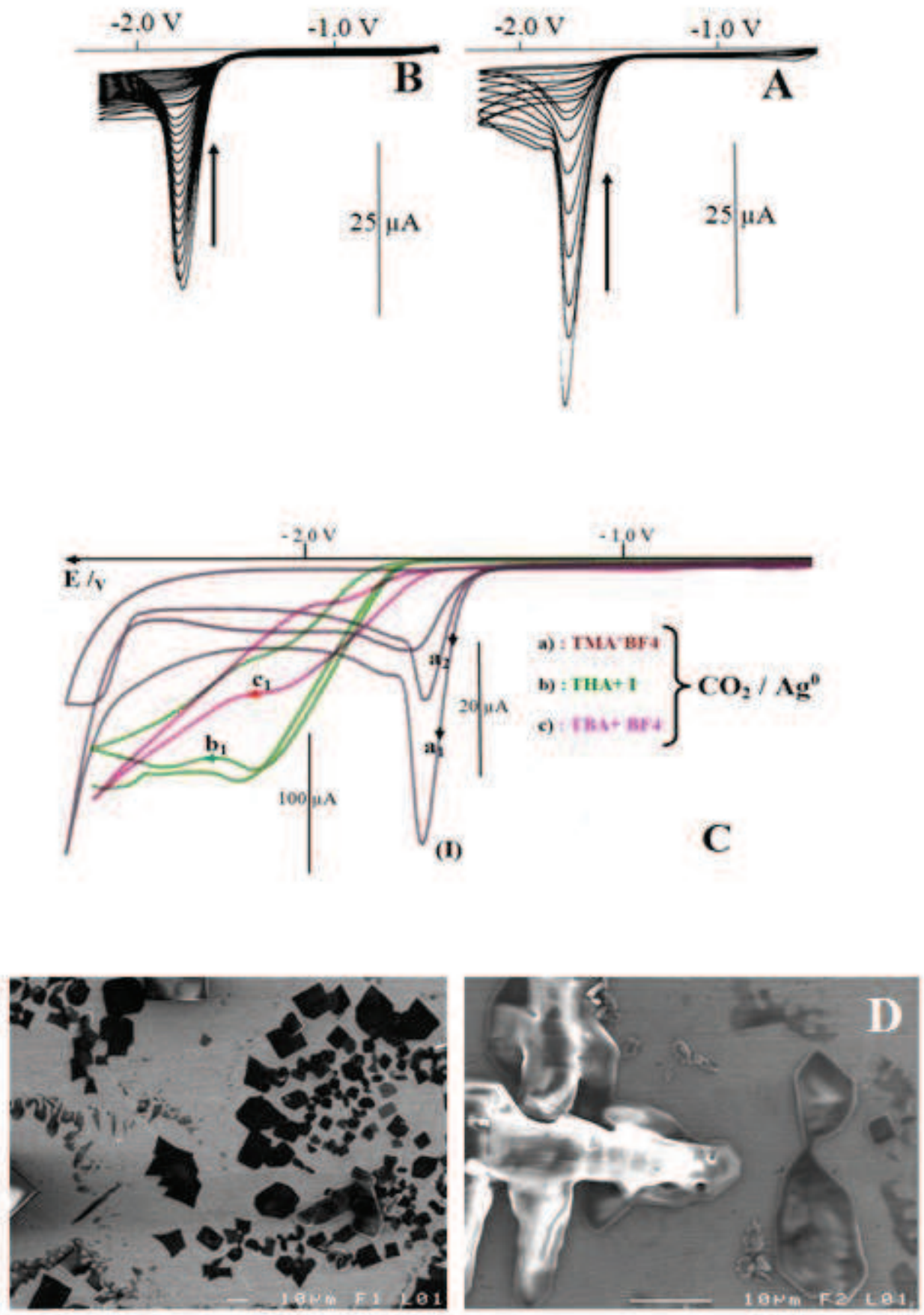

Figure 1 

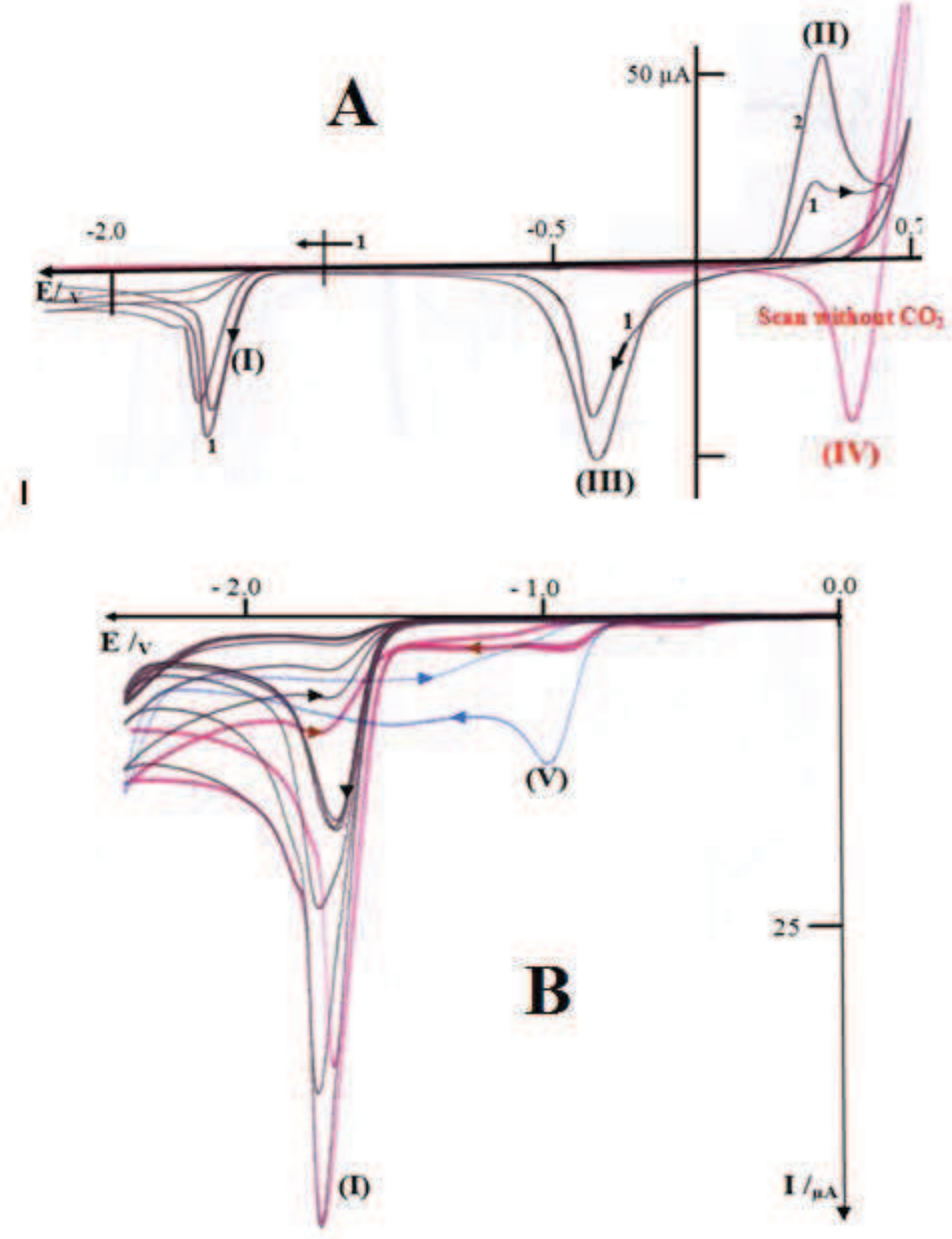

Figure 2 


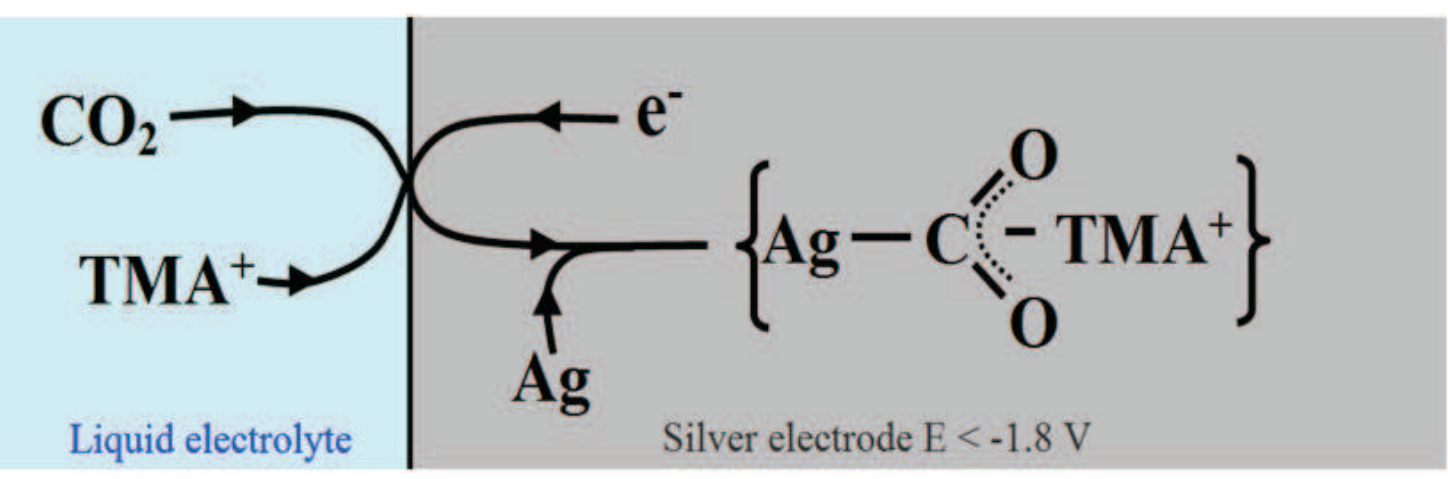

$\mathrm{Ag}++\mathbf{C O}_{\mathbf{2}}+\mathbf{M}^{+}+\mathbf{e}^{-} \frac{\mathrm{M}^{+}=\left(\mathrm{TMA}^{+}\right)}{\mathrm{Step} \mathrm{I}}\left\{\mathbf{A g - \mathbf { C O } _ { 2 } - \mathbf { M }}\right\}_{\mathrm{s}}$

$\left\{\mathrm{Ag}-\mathrm{CO}_{2}-\mathrm{M}\right\}_{\mathrm{s}}-\mathrm{e}^{-} \longrightarrow$ Step II $\longrightarrow\left\{\mathrm{Ag}-\mathrm{CO}_{2}-\mathbf{M}\right\}_{\mathrm{s}}{ }^{+}$

$\left\{\mathrm{Ag}-\mathrm{CO}_{2}-\mathrm{M}\right\}_{\mathrm{s}}{ }^{+} \quad$ Scission $\longrightarrow \quad \mathbf{A g}_{\mathrm{s}}^{+}+\left(\mathrm{CO}_{2}\right)_{\mathrm{s}}+\mathbf{M}_{\mathrm{s}}^{+}$

$$
\mathbf{A g}_{\mathrm{s}}^{+}+\mathbf{e}^{-} \stackrel{\text { Step III }}{\longrightarrow} \mathbf{A g}^{0}
$$

$\left(\mathrm{CO}_{2}\right)_{\mathrm{s}}+\mathrm{Ag}^{0}+\mathrm{M}^{+}+\mathrm{e}^{-} \longrightarrow\left\{\mathrm{Ag}-\mathrm{CO}_{2}-\mathrm{M}\right\}_{\mathrm{s}}$

$$
\left\{\mathrm{Ag}-\mathrm{CO}_{2}-\mathrm{M}\right\}_{\mathrm{s}}+\mathrm{RI} \longrightarrow \mathrm{E.T.} \mathbf{R}^{*}+\mathrm{Ag}_{\mathrm{s}}^{+}+\left(\mathrm{CO}_{2}\right)_{\mathrm{s}}+\mathbf{M}^{+} \mathbf{I}^{-}
$$

Scheme 1 


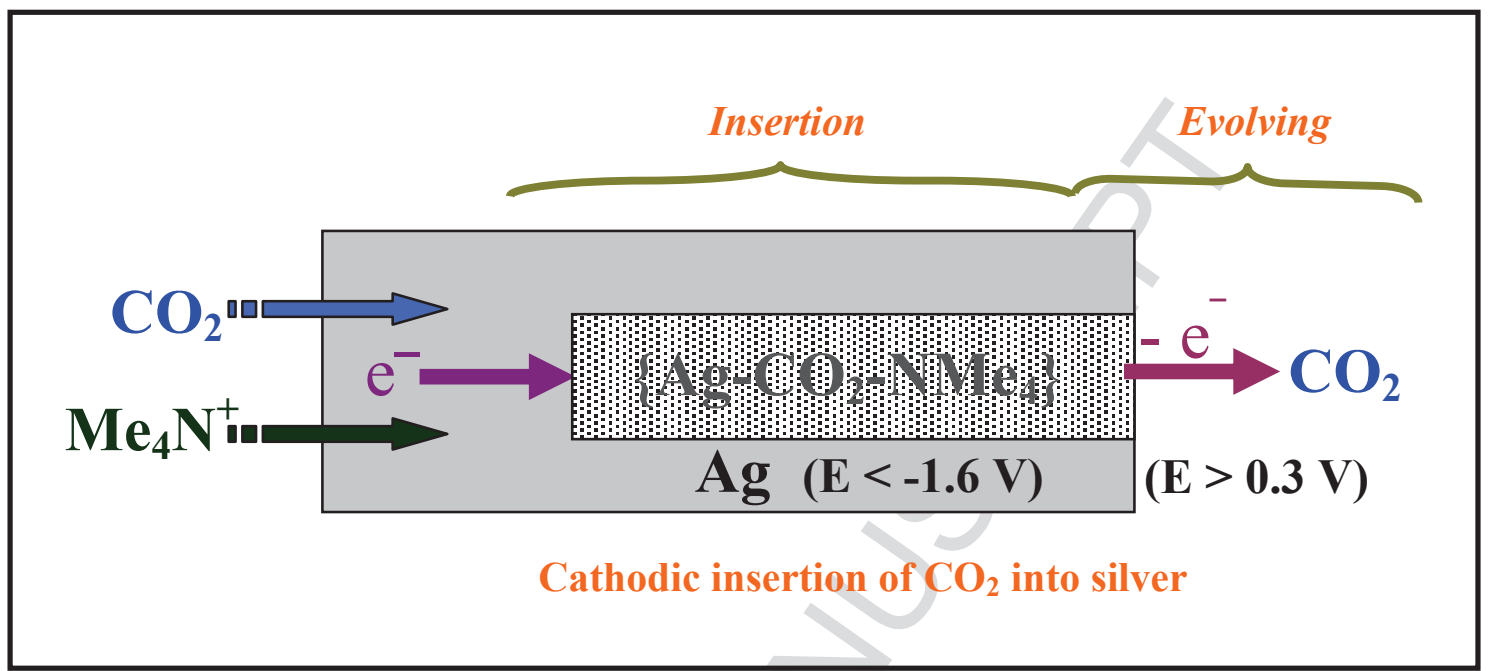

Graphical Abstract 


\section{Highlights}

Large electrochemical insertion of carbon dioxide in massive silver $>$ Surfacial decoration versus mass modification $>\mathrm{Ag}-\mathrm{CO}_{2}$ - electrolyte cation transient for a new solid material $>$ Specific use of tetramethylammonium salts for a successful mass carboxylation $>$ Stocking $\mathrm{CO}_{2}$ with evolving under anodic electron transfer. 